\title{
Thinking with the diver: the Mediterranean in historical perspective
}

\section{Iain Chambers}

Abstract: This paper considers the Mediterranean as an archive. Here the contemporary migration 'crisis', imbricated in the asymmetrical relations of power that sustain the superficial tenets of geopolitics, are intersected by deeper histories and longer rhythms. The latter propose a critical revaluation that bring the colonial-capitalist-racistcoordinates of modernity sharply into view.

Keywords: Mediterranean, modernity, migration, colonialism.

Author: Iain Chambers is Professor of Sociology at the University of Naples, 'L'Orientale', where he teaches Cultural and Postcolonial Studies of the Mediterranean. Author of Migrancy, Culture, Identity (1993, Routledge) and Mediterranean Crossings (2008, DUP), his recent publications include Postcolonial Interruptions, Unauthorised Modernities (2017, Rli), and La Questione Mediterranea (2019, Mondadori Università). i.chambers@icloud.com

(C) The author(s) 2020. This is an open access article licensed under a 
To view the contemporary Mediterranean, with ports on its northern shores closed to migrants and its waters patrolled by Libyan coastguards financed by Europe to intercept and return them to camps in the North African desert, is to register a maritime barrier. Such barriers are fundamentally about the right of the state to control movement. No one is born illegal, but many are redefined as such, arrested and excluded from the ability to exercise their rights. To reach and cross such barriers is to expose the violence that underpins the modern state, the way in which its citizenship is defined and the legalistic brutality of its defence. We all are witnesses to this. We are constantly reminded, perhaps numbed, by the media relaying the accumulating body count from the Mediterranean Sea, the savagery of life in the migrant camps in Libya, and the conditions in the migrant reception centres within Europe itself. Such borders are not simply external barriers. For they are also linked to the increasing surveillance and retraction of the exercise of rights implicit in contemporary citizenship.

Confronting and contesting this requires recourse to another cultural and political economy. It means to tap into the deeper histories that have brought us to where we are today. By bringing into the present precisely what the present seeks to obscure, we can perhaps reveal the potential of the past to contribute to a diverse political contemporary agenda.

If we look at a map of the Mediterranean, everything is laid out flat. Borders are clearly defined. All is seemingly captured by the eye, rendered measurable and knowable. This is the basis for the geopolitical chess board where everything is in a spatial relationship to everything else. It apparently provides an objective rendering of reality. It appeals to a liberal organisation of the world where all the actors are treated as though equal, permitting the analysis to remain 'balanced' and 'impartial'- something that is not always possible to sustain when considering present-day relationships between the northern and southern shores of the Mediterranean.

To think with the Mediterranean, that is to go off-shore and float in its diverse currents, is to consider the manner in which it constitutes an interrogative archive and counter-space to the prevalent understanding of modern Europe. Both in, but not completely of, Europe, the making of the modern Mediterranean as a subaltern historical and cultural formation interrupts the logic that the world can simply be laid out flat as a map. To reopen this archive, we could consider how its multiple histories and cultural formations propose a diverse series of maps and coordinates. To reassemble the fragments of the past in this manner is to construct an alternative sense of the present. 


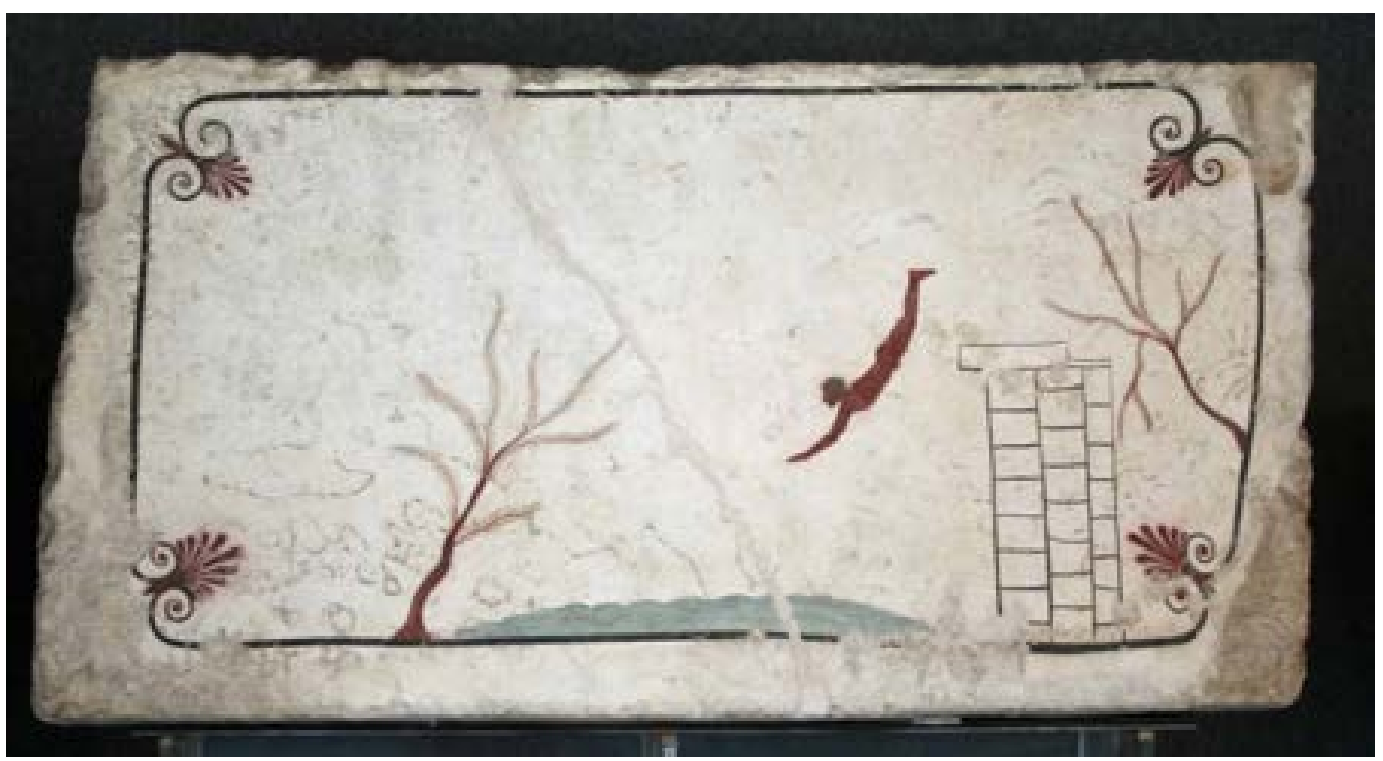

Figure 1. Tomb of the Diver, National Archaeological Museum of Paestum.

\section{THINKING WITH THE DIVER}

Inside a tomb, rediscovered fifty years ago by the archaeologist Mario Napoli during his excavation of a necropolis south of the Greek city of Paestum in southern Italy, we see a distinctly dark male body that belies the 19th-century view of Hellenism and the transformation of Jesus Christ, the Virgin Mary, together with Greek gods and heroes, into white Aryans. Some two thousand five hundred years ago, a body descends gracefully through the air, staring wide-eyed into the future. This famous painting on the inside of the lid of a sarcophagus (La Tomba del Tuffatore), destined to invisibility, lights up the present in an emergent reconfiguration of the past. This lithe figure, in full flight, is surrounded on the four internal sides of the tomb by reclining male figures constituting a symposium. It comes from the Greek settlement of Poseidonia, better known by its Roman name of Paestum, which lies on the Tyrrhenian coast south of Salerno near the mouth of the river Sele. As a Greek colony, Paestum was part of the expansion of the Peloponnesian city states that stretched over Homer's 'wine-dark sea' into Asia Minor, northwards to the steppes bordering the Black Sea, and westwards through Sicily and southern Italy to the coastlines of modern France and Spain. Like all colonialisms, the Greek expansion involved conquest, together with the subjugation and enslavement of indigenous populations. The land, as always, was never empty. Control had to be wrested from local authority. Blood would have been 
spilt, lives arbitrarily terminated, followed by the imposition of an imported culture and political organisation. Today, much of this detail falls away, lost in the myths of a European nostalgia for the presumed purity and nobility of its origins. Yet it is deeply etched into the architectural grammar of contemporary Occidental cities where neoclassical buildings imitate the illusory whiteness of Antiquity. We find this purposeful whitewashing of the past everywhere: from the massive urban interventions in Fascist Italy to present-day London, Paris, Berlin and Washington. The temples of Paestum, however, as elsewhere in the classical world, would have been decorated in vivid colours.

This is to think with, and follow, the reverberations revealed in the profound anachronism of the way in which we think and write about history. Opening the tomb, opening the archive, is to suggest a set of connections and coordinates with which we could choose to navigate the Afro-Asian-European matrix of the Mediterranean. Of course, without abandoning the skilled, disciplinary competence that has brought the past to light, this also means refusing to reduce its materials to a single inventory of time. It is to adopt a more ironic relationship to origins. In a sort of archaeology of archaeology, we are seeking to uncover another genealogy that does not merely mirror a European will to power.

To insist on the anachronistic as method, and consider what Reinhart Koselleck called the 'historical determination of time', is to unsettle an established consensus in which the conditions of semantic, cultural and political production are consigned to their 'origins' in a seemingly separate past. ${ }^{1}$ Now they need constantly to renegotiate their presence in today's world. So, drawing out of the very heartland of European civilisation, its Greek and Mediterranean 'origins', another set of questions, we can encounter further geographies of understanding, other axes of interpretation that render that seemingly distant past both proximate and potentially disruptive. The flat taxonomy of time, everything in its assigned chronological and cultural place, is abruptly interrupted and cut up, ready for another collage of comprehension.

Like the painting of the diver, executed for unseeing eyes, but now recovered and exposed, we can consider other hidden and sedimented matters that propose other memories. This is to raise questions of property and ownership: who has the right to narrate and why? Under what sort of genealogy is memory owned and authorised? Seeking to reply brings us to propose a shift in the existing premises of the human and social sciences and their actual legislation on such questions and prospects. Breaking apart the philological imperative of linearity and reassembling its elements in another configuration invites us to take a deeper responsibility for our language; recognising its transitory precariousness and its perpetual vulnerability to investment by a past we

${ }^{1}$ Koselleck (2002). 
can never fully recover nor own. A past, which in still being assembled and recognised, comes to us from the future.

This means to return objects to the density of both their cultural lineage, their resonance in the echo chambers of historical memories and their archival connection to a tomorrow. Of course, this is to return history itself to another history and to cut the cord with the security of scientific neutrality as the guarantee of our language and knowledge. It is to take responsibility both for language and memory.

Exchange, conflict, cooperation and co-presence emerge as the arbiters of difference, with the Mediterranean existing as a mutable space of adjacent and overlapping cultural and historical currents, defying neat cartographic or civilisational delineations of national identity. Recognising in Greek colonisation around the Mediterranean not simply a seaborne empire but also the violent evidence of diaspora and exile from the Greek cities that inaugurated the colonial undertaking is to open a hole in time, connecting that past with contemporary concerns. Practising colonisation, disciplining the territory according to a determined cultural order, experiencing, contesting and absorbing hybridisation, were central to the experience of Paestum some two and a half thousand years ago. All of which suggests a set of reverberations with the contemporary world. This is to establish an archipelago that is not simply spatial and geographic, but also temporal, and which allows us to island hop across time, seeking through the undeniable singularities we encounter the common factors that render the past comprehensible to future endeavours.

This means to insist that the archaic and the past are not back there, safely locked away in a dead time, but continue to constitute the constellation of the present. Following Gramsci, ${ }^{2}$ we could say this means to turn the relation between past and present, between the archaic and the modern, $180^{\circ}$ to recognise the repressed and the refused in the modern modalities of the subaltern. How might the fractures of belonging in Europe be healed by an awareness of the deep history of the Mediterranean as a meeting ground and crossing point between cultures?

While the figure of the diver in the tomb is evidence of a hybridising culture-Greek in southern Italy bordering on, and intermingling with, Etruscan, Roman and Lucanian - it also points us towards a Mediterranean characterised by migration. The latter clearly offered hospitality to many peoples and multiple directions: Phoenician, Greek, Carthaginian, Roman, Byzantine, Arab, Norman, Genoese, Venetian, Ottoman, ... To think with these terms and histories is once again to break open the archive and insist on a fluidity that overflows the terrestrial confines of what today is predominantly a national narration of this complex geo-history. Further, it is to bring to many of today's political and academic symposiums deeper discussions that

\footnotetext{
${ }^{2}$ Gramsci (1978).
} 
transform the question of modern migration from its frequent marginalisation in socio-economic terms to considering it as both the motor of Mediterranean cultures and of modernity itself.

If mass migration is modernity, then the movement back and forth across Mediterranean waters, both south to north and north to south, is the result of a common hubris on the part of the northern states driven by a transnational political economy and the unification of the world by capital. At the beginning of the 20th century, the European population of Algeria (the Ottoman province colonised by France in the 1830s) was close to one million, the majority French, alongside sizeable components of Spanish and Italians. Tunisia next door, likewise a French colony, had an Italian population of 100,000, while Libya (another Ottoman territory, invaded by Italy in 1911) had an Italian population that peaked in the 1930s at around 13 per cent of the total. What is occurring today with migrations towards the overdeveloped north of the planet is the latest episode in a long narrative. From the transatlantic slave trade to contemporary migrations, there are clearly differences but also deep, underlying continuities that could permit us to write the history of modernity precisely as the history of migration and diasporas.

At this point, questions of belonging cross our juridical, cultural and historical borders with unanswered questions. The authorisation of citizenship, the right to narrate, the right to have rights, ${ }^{3}$ disturb and unravel existing political settlements. The contemporary migrant becomes the critical cypher, the non-person whose practice and presence operate a cut in the narrative while consistently decoding the asymmetrical relations of power that orchestrate the violence of the present. Here, for example, the connections between Black Lives Matter and the Palestinian cause unveil a counter-history of the neoliberal global order, whereby the populations from Africa now settled in the US and Europe are at risk of violence from functionaries of the state, while the Arab inhabitants of historical Palestine are unable to exercise their rights in the state which has been established by immigrants from Europe and to a lesser extent the US. To refuse to erase the populations that through their presence and survival expose the wounds and cuts on the body of modernity that the usual maps refuse to chart and indicate is to touch the depth of naming today's Mediterranean 'a black Mediterranean'. All of this involves critical choices in which disciplinary procedures are entangled in ethical proposals.

In his account of the city of Salonica under the Ottomans (1430-1925), the historian Mark Mazower references a world concentrated in the monotheisms of the Mediterranean: those religions of the desert (Judaism, Christianity and Islam) that

\footnotetext{
${ }^{3}$ Arendt (1951).
} 
developed in transcultural diffusion. ${ }^{4}$ The history of Salonica emerges from a montage of intertwined narratives that speak in terms of pauses, breaks and oblivion. His history concludes in the actual Greek city of Thessaloniki. Here we encounter the ruins and cancellation of the historical, cultural, political and religious composition of an urbane Ottoman world and the imposition of Hellenic nationalism followed by Fascism. If in 1923 the Muslim population of the city was exchanged with the Greek one in Anatolia, between 1943 and 1945 the Nazis exterminated the Sephardic Jewish population of the city in the death camps of Eastern Europe. Alongside the terrible cost of ethnic cleansing, already encouraged by the push for national homogeneity, lies the importance of the counter-history of the ghosts announced in the title of Mazower's study. The refusal to remember is as significant as the official insistence on conserving a historical continuity based on oblivion. As Freud understood, visiting the ruins of Rome, such sedimented sites of memory, exposed to what has been negated, refused and consigned to silence, render our knowledge, explanations and management of the world vulnerable, susceptible to doubt, entangled in interrogation and interpretation.

Faced with bodies of migrants denied, rejected and left to drown, we find ourselves undoing the premises that have managed and explained the Mediterranean. Removing that picture from a single register, respecting the complexity of its historical and cultural formation, involves not simply reintroducing denied stories and voices, or opting for the other shore and pretending to be able to see the world from the subaltern perspective. It means dismantling the assumptions of the knowledge and languages that have brought us here; not to delete them, but to expose them in another, unauthorised, configuration and to acquire a critical apprenticeship in speaking in its proximity. Perhaps from here we can begin to consider how to reinvent both Europe and modernity.

\section{REFERENCES}

Arendt, H. (1951), The Origins of Totalitarianism (New York, Schocken Books).

Gramsci, A. (1978), 'Some Aspects of the Southern Question (1926)', from Selections from Political Writings (1921-1926), translated Q. Hoare (London, Lawrence and Wishart).

Koselleck, R. (2002), The Practice of Conceptual History: Timing, History, Spacing Concepts, translated by T. S. Presner, K. Behnke \& J. Welge (Stanford, CA, Stanford University Press).

Mazower, M. (2005), Salonica, City of Ghosts: Christians, Muslims and Jews, 1430-1950 (New York, HarperCollins).

${ }^{4}$ Mazower (2005) 
To cite the article: Iain Chambers (2020), 'Thinking with the diver: the Mediterranean in historical perspective', Journal of the British Academy, 8(s1): 5-12.

DOI https://doi.org/10.5871/jba/008s1.005

Journal of the British Academy (ISSN 2052-7217) is published by

The British Academy, 10-11 Carlton House Terrace, London, SW1Y 5AH

www.thebritishacademy.ac.uk 